\title{
A Comparative Study of Academic Achievement of Undergraduates from Intact and Broken Homes in Obafemi Awolowo University, Ile-Ife, Osun State, Nigeria
}

\author{
Dr. B. A. Adeyemi* \\ Institute of Education, Obafemi Awolowo University, Ile-Ife, Osun State, Nigeria
}

*Corresponding Author: Dr. B. A. Adeyemi, Institute of Education, Obafemi Awolowo University, IleIfe, Osun State, Nigeria

\begin{abstract}
The study investigated the academic achievement of the undergraduates from intact home as well as broken home. It also examined the factors contributing to broken homes from undergraduate perspectives and investigated if there was any significant difference in the academic achievement of undergraduate from intact and broken homes; these were with the view to improving academic achievement of undergraduates from intact and broken homes in Obafemi Awolowo University, Ile-Ife. The study employed survey research design. The population consisted of undergraduates of Obafemi Awolowo University, Ile-Ife. Simple random sampling technique was employed in selecting three Faculties in the University, comprising Education, Administration and Arts. Purposive sampling technique was equally employed in selecting fifty students in each of the three faculties comprising undergraduate from intact and broken homes. An instrument was constructed by the investigator to elicit information from the respondents. Data collected were analyzed using simple percentages, RSI, and t-test statistics. The results showed that there was no significant difference in the academic achievements of undergraduates from intact homes and broken homes $(t=67.42, p>0.05)$. The study concluded that some of the factors which caused academic failures are linked to pre-marital cohabitation and pre-marital childbearing, socio economic status and insecurity as well as early marriage and couples with divorced parents.
\end{abstract}

Keywords: Undergraduates, Intact Home, Broken Home, Academic Achievement

\section{INTRODUCTION}

The concept of marriage has gone beyond general parlance; this is to say that individual now attributes personal meaning to the subject matter of marriage which does not go hand in hand with norms and value of the society where such values are being promoted. If one is to examine parental goals, it would not be an over simplification to conclude that realizing these goals requires children to possess the inner strength to deal competently and successfully day after day with the challenges and demands they encounter. The above statement could be made clearer in the view of the Tre (2005), who opined that marriage is a life-long contract that is not easily broken. When the contract is broken, the resulting divorce has an effect on the entire family.

An undergraduate is a student in a university or college who has not received a first, especially a bachelor degree. According to Adeyemi (2017), tertiary institutions are higher institutions of learning that cater for different categories of learners in such a way that they accommodate both married and unmarried persons. He went further that some of the students who have not been joined together as husband and wife live like couples both on and off campuses. It is therefore not a gainsaying to say that children that are born through any of the aforementioned above means could eventually fall within intact or broken homes.

There are many different types of families which include intact, non-intact, single families, stepfamilies and a variety of others. Along with these different varieties of families, there is one common incident that can cause the family structure to change. A broken home in this context is one that is not structurally intact, as a result of divorce, separation, death of one of the parents and illegitimacy.

According to Frazer (2001), psychological home conditions arise mainly from illegitimacy of children, the label of adopted child, broken homes, divorce and parental deprivation. Such abnormal 
conditions in the home are likely to have a detrimental effect on the performance of the child at school. Life, in a single parent family or broken home, can be stressful for both the child and the parents. Such families are faced with challenges of inadequate financial resources (Children Defense Fund, 2004). Schults (2006) noted that if people from unstable homes are to be compared with those from stable homes, it would be seen that the former have more social, academic and emotional problems. Agulana (2005) asserted that children of unmarried parents/separated families often fail and are at risk emotionally. However, this may not be completely applicable in all cases of broken homes. According to Hargreaves (1991), student's resilience in a one-parent household is believed to be a significant indication of success in other areas of their lives, including academics. Divorce is an unplanned event in a family's life. It is something that affects each member of a family at different times and in different ways. About half of all marriages will end in divorce, leaving one million children each year to deal with the process of divorce (Laura, Specter \&Martin, 2009).

Akanbi (2014) defined divorce as a legal dissolution of marriage bond. Once the couple decides to divorce, they are free to remarry again. This is not same as separation of married couples, who out of grievances, decide to live apart by avoiding each other for a long period of time before deciding to resolve their differences and coming together again on agreed terms without any legal means or involvement but through family interference. Though the two concepts, (divorce and separation), could be used interchangeably, yet they differ significantly. It is so because many Africans are governed by traditional believe where divorce is not celebrated or welcomed by anyone. Nigeria is a good example of such African countries. Families come together to help couples settle their differences unlike the western believe where couples use just a "single phone call to put an end to a marriage that is barely a year". This is because the home, in the context of a child, affects his reaction to life situations and his level of performance at school, not only the school, the family as well is tagged and identity dented, by so doing prospective couples in the future may not be allowed to associate with people from broken homes or single parents.

According to Omoruyi (2014), academic performance is seen as the knowledge attained or skills, shown in the school subject. To indicate such achievement, test scores or marks are assigned by the teachers. It is the school evaluation of the classroom work on the basis of the grades awarded. Academic performance according to Akinboye (2006) is of two types i.e. positive and negative (poor) performance. Habits, family background, perseverance, attitudes, interest - all these affect academic achievement in school. He concluded that if these variables are modified and attitude changed positively, then the level of individuals' academic performance would improve. Academic achievement is an essential consideration in measuring success in students. Survey and research reports have shown that high academic achievement has become an enormous task to be accomplished by students in recent times. Poor academic performance was recorded both at the secondary and tertiary levels of education in Nigeria (Tenibiaje, 2009). The performance of students at any level in educational institutions in Nigeria has attracted much criticism. The decline in the academic performance of students in Nigeria needs restructuring. He further highlighted the academic need for standards which had fallen drastically and the quality of graduates being produced by the nation's universities is questionable and subject to re-examination.

Poor academic achievement of students has been of great concern to educationists, Measurement and Evaluation experts as well as guidance counselors. Despite all guidance programames and counseling strategies mounted in schools to improve students' academic performances yet poor performances are recorded yearly. Ushie, Emeka, Ononga, and Owolabi (2012) further cited the view of Ajila and Olutola (2007), that the home has a great influence on the child's psychological, emotional, social and economic states. In his view, the state of the home affects the individual since the parents are the first socializing agents in an individual life. This is because the family background and context of a child affect his reaction to life situations and his level of performance. Family structure in terms of single and two parent families had been noted in their literature to have a significant influence on students' performance and mental development (Yusuf \& Eweniyi, 2005). This is because providing a supportive learning environment at home requires parents' time as much as financial resources.

According to Salami and Alawode (2000), the existence of single-parents in Nigeria is formerly unknown and where they existed, they are ignored as exceptional cases. However, nowadays, it is a fast-growing family patterns both inside and outside Nigeria. Although there are no available statistics of single-parent families in Nigeria (Salami \& Alawode, 2000), practical experience and newspaper 
reports show that there is an increase of single-parents in Nigeria. In the western countries, there is a growing increase in the percentage of adults and children living in single parent households. Laura, Specter, Martin and Martin (2009) stated that divorce rates in the United State rose since the Civil war. Single-parent families live on average lower income than two-parent families and are thus more constrained in ensuring adequate financial resources to meet their children's learning needs. In addition, since single parents must cope with the double responsibility of work and child-rearing. It may be more challenging for them to provide and maintain a supportive learning environment for their children (OECD/UNESCO, 2003).Studies have shown that before parental divorce, children and adolescents suffer due to high levels of marital discord; ineffective and inconsistent parenting diminished parental wellbeing, and reduced parent-child affection, [(Rodgers \& Pryor (1998), Demo $\& \operatorname{Cox}(2000)]$.

Hence, healthy child and youth development is often associated with support and affection from one or more adults as a buffer to the effect of risk. The interest of this study is in finding the relationship between these two phenomena (divorce and academic achievement) in reference to university students' academic achievement. Though many parents of students may have experienced a divorce earlier in childhood, it may still play a role in their everyday lives. In investigating this topic, the goal was to answer whether or not a certain degree of academic deficits are prevalent during university education. In conclusion, the university is a place of research interest where those who lack parental support issues may struggle academically. These individuals may have trouble coping with the large amount of stress and personal freedoms that come with higher cadre institutions. To examine broken home and the relationship between the broken home and the child to academic success, this research work surveyed students coming from broken homes, as well as those of intact families.

\section{Statement of the Problem}

Studies in the past (Nzewunwah, 1995, Maduewesi \& Emenogu, 1997; Ichado, 1998; Salami \& Alawode, 1999; Frazer, 2001; Okoye, 2013; Salami, 2008; Hamilton-Ekeke, 2014 \& Omoruyi, 2014), have dealt with influence of home on academic performance of secondary school students, majority of which were adolescents. Among the undergraduates in Nigerian Universities today, we have some that have passed through adolescence stage, not only that, in Nigeria as of today, there is dearth of literature on comparative analysis of undergraduates academic achievement with respect to the types of homes they came from. It is on this background that this study was on comparative study of academic achievement of undergraduates from intact and broken home in a Nigerian University.

\subsection{Purpose of the Study}

The objectives of this study are to:

- investigate the academic achievement of the undergraduate from intact home;

- investigate the academic achievement of undergraduates from broken homes;

- examine factors contributing to broken homes from undergraduates perspectives; and

- investigate if there is any significant difference in the academic achievement of undergraduates from intact and broken homes.

\subsection{Significance of the Study}

The study investigated significant difference between intact and broken homes on undergraduates' academic performance in schools. Based on the findings of the study, suggestions and recommendations would be made to educational planners, Education authorities o the guidelines that should be given to students that might have problem resulting from broken homes. It will also help in a long way in educating educational counsellors on the appropriate ways of helping the students from such homes and in adjusting to the society effectively as against the negative threat of divorce to undergraduates' academics.

\subsection{Research Questions}

The research questions of the study are as follows:

- What is the academic achievement of the undergraduates from intact homes?

- What is the academic achievement of the undergraduates from broken home? 
A Comparative Study of Academic Achievement of Undergraduates from Intact and Broken Homes in Obafemi Awolowo University, Ile-Ife, Osun State, Nigeria

- What are the factors contributing to broken home from the perspectives of the undergraduates?

\subsection{Hypothesis}

- There is no significant different in the academic achievement of the undergraduates from intact and broken homes.

\section{METHOD}

The study employed survey research design. The target population for the study consisted of the Obafemi Awolowo University students in Ile-Ife. The study employed a simple random sampling technique consisting of 150 respondents from three faculties within the Obafemi Awolowo University community. The three faculties (Education, Administration and Arts) were selected using purposive sampling technique which consisted of fifty students in each faculty comprising of undergraduates from both broken and intact homes. Both primary and secondary data were employed in eliciting information from the respondents. The questionnaire was duly validated before used. The questionnaire was administered among Obafemi Awolowo University students in the three faculties. Also, records on the performances of the sampled undergraduates were collected from their respective faculties. Statistical Package for Social Sciences (SPSS) was used to analyze the data collected. The data were arranged in the required format and keyed into the software for the processing. The data were analyzed using frequency counts, simple percentages, Relative Significance Index (RSI) and independent t-test respectively.

\section{Results}

The results were presented according to the research questions raised earlier as shown in the tables below:

Research Question 1: What is the academic achievement of the undergraduates from intact home?

In order to answer this research question, Cumulative Grade Points Average (CGPA) as supplied from the selected faculties based on sample size of the undergraduates from intact home was subjected to descriptive analysis. The result is presented in Table 1 below.

Table1. Academic Achievement of the Undergraduates from Intact Homes

\begin{tabular}{|l|l|l|}
\hline \multicolumn{1}{|c|}{ Achievement Level } & Frequency (f) & \multicolumn{1}{c|}{ Percentage (\%) } \\
\hline Pass & 3 & 2.9 \\
\hline Third Class & 9 & 8.7 \\
\hline $2^{\text {nd }}$ Class Lower & 33 & 31.7 \\
\hline $2^{\text {nd }}$ Class Upper & 45 & 43.3 \\
\hline First Class & 14 & 13.3 \\
\hline Total & 104 & 100.0 \\
\hline
\end{tabular}

Table 1 shows the academic achievement of undergraduates from intact homes. It can be observed that $2.9 \%$ of the undergraduates from intact homes were on Pass, $8.7 \%$ Third Class, $31.7 \%$ Second Class Lower, $43.3 \%$ Second Class Upper while $13.5 \%$ of the undergraduates were on First Class level. There is an indication from this result that academic achievements of the undergraduates from intact homes are hovering around Second Class Upper and Second Class Lower as $75 \%$ of the undergraduates were found in these categories.

Research Question 2: What is the academic achievement of the undergraduates from broken home?

In order to answer his research question, Cumulative Grade Points Average (CGPA) as supplied in the selected faculties based on sample size of undergraduates from broken home was subjected to descriptive analysis. The result is presented in Table 2 below.

Table2. Academic Achievement of the Undergraduates from Broken Homes

\begin{tabular}{|l|l|l|}
\hline \multicolumn{1}{|c|}{ Achievement Level } & Frequency (f) & \multicolumn{1}{|c|}{ Percentage (\%) } \\
\hline Pass & 3 & 7.5 \\
\hline Third Class & 1 & 2.5 \\
\hline $2^{\text {nd }}$ Class Lower & 15 & 37.5 \\
\hline $2^{\text {nd }}$ Class Upper & 17 & 42.5 \\
\hline
\end{tabular}


A Comparative Study of Academic Achievement of Undergraduates from Intact and Broken Homes in Obafemi Awolowo University, Ile-Ife, Osun State, Nigeria

\begin{tabular}{|l|l|l|}
\hline First Class & 4 & 10.0 \\
\hline Total & 40 & 100.0 \\
\hline
\end{tabular}

Table 2 shows the academic achievement of undergraduates from broken homes. It can be observed that $7.5 \%$ of the undergraduates from broken homes were on Pass, $2.5 \%$ Third Class, $37.5 \%$ Second Class Lower, $42.5 \%$ Second Class Upper while $10.0 \%$ of the undergraduates were on First Class level. There is an indication from this result that academic achievement of considerable percentage of the undergraduates from broken homes are hovering around Second Class Upper and Second Class Lower as $80 \%$ of the undergraduates were found in these categories.

Research Question 3: What are the factors contributing to broken home from the undergraduates' perspectives?

In order to answer this research question, items under factors such as A: pre-marital cohabitation and pre-marital child bearing. B: socio-economic status and insecurity, C: early marriages and couples with divorced parents were subjected to a descriptive analysis. The result is presented in Table 3 below.

Table3. Factors Contributing to Broken Home

\begin{tabular}{|c|c|c|c|c|c|c|c|c|c|c|}
\hline \multirow[t]{2}{*}{$\mathbf{S} / \mathbf{N}$} & \multirow[t]{2}{*}{ Factors } & \multicolumn{2}{|r|}{$\mathbf{A}$} & \multicolumn{2}{|c|}{$\mathbf{S A}$} & \multicolumn{2}{|c|}{$\mathbf{D}$} & \multicolumn{2}{|c|}{ SD } & \multirow[t]{2}{*}{ RSI } \\
\hline & & $\mathbf{F}$ & $\%$ & $\mathbf{F}$ & $\%$ & $\mathbf{F}$ & $\%$ & $\mathbf{F}$ & $\%$ & \\
\hline $\mathbf{A}$ & \multicolumn{10}{|c|}{ Pre-marital cohabitation and Pre-marital childbearing } \\
\hline 1 & $\begin{array}{l}\text { I see nothing wrong in living with a guy before } \\
\text { marriage.Living together may be a way to get } \\
\text { to know each other better. }\end{array}$ & 22 & 15.3 & 16 & 11.1 & 41 & 28.5 & 65 & 45.1 & 0.481 \\
\hline 2 & $\begin{array}{l}\text { Couples who live together before marriage } \\
\text { appear to have a much higher chance of } \\
\text { divorce if they marry. }\end{array}$ & 60 & 41.7 & 21 & 14.6 & 45 & 31.3 & 18 & 12.5 & 0.646 \\
\hline 3 & $\begin{array}{l}\text { Cohabitation is to an extent a way to test } \\
\text { couples compatibility before marriage. }\end{array}$ & 38 & 26.4 & 13 & 9.0 & 51 & 35.4 & 42 & 29.2 & 0.538 \\
\hline 4 & $\begin{array}{l}\text { Cohabitation is one of the reasons why } \\
\text { marriages lead to divorce. }\end{array}$ & 59 & 41.0 & 18 & 12.5 & 50 & 34.7 & 17 & 11.8 & 0.635 \\
\hline 5 & $\begin{array}{l}\text { Cohabitation could be said to arouse suspicion } \\
\text { between married couples leading to divorce. }\end{array}$ & 72 & 50.0 & 20 & 13.9 & 38 & 26.4 & 14 & 9.7 & 0.670 \\
\hline 6 & $\begin{array}{l}\text { Pregnancy and childbearing prior to marriage } \\
\text { significantly increase the likelihood of future } \\
\text { divorce. }\end{array}$ & 50 & 34.7 & 40 & 27.8 & 39 & 27.1 & 15 & 10.4 & 0.700 \\
\hline $\mathbf{B}$ & \multicolumn{10}{|c|}{ Socio-economic status and insecurity } \\
\hline 7 & $\begin{array}{l}\text { Challenges leading to divorce could be traced } \\
\text { to low income within the household }\end{array}$ & 69 & 47.9 & 30 & 20.8 & 30 & 20.8 & 15 & 10.4 & 0.698 \\
\hline 8 & $\begin{array}{l}\text { Would you feel disappointed if your parents } \\
\text { argue over money? }\end{array}$ & 56 & 38.9 & 48 & 33.3 & 32 & 22.2 & 8 & 5.6 & 0.750 \\
\hline 9 & $\begin{array}{l}\text { Having at least a modest income can help } \\
\text { couples avoid stress that can lead to divorce }\end{array}$ & 84 & 58.3 & 39 & 27.1 & 16 & 11.1 & 5 & 3.5 & 0.773 \\
\hline 10. & $\begin{array}{l}\text { Would it be good for a woman to divorce the } \\
\text { husband to marry another due to financial } \\
\text { recklessness? }\end{array}$ & 26 & 18.1 & 14 & 9.7 & 63 & 43.8 & 41 & 28.5 & 0.523 \\
\hline \begin{tabular}{|l|}
11 \\
\end{tabular} & $\begin{array}{l}\text { Insecure individuals are more likely to become } \\
\text { unhappy in their marriages over time and } \\
\text { divorce }\end{array}$ & 64 & \begin{tabular}{|l|}
44.4 \\
\end{tabular} & 54 & 37.5 & 16 & 11.1 & 10 & 6.9 & 0.781 \\
\hline C & \multicolumn{10}{|c|}{ Early marriage and couples with divorced Parents } \\
\hline 12 & $\begin{array}{l}\text { Marriage at a very young age increases the } \\
\text { likelihood of divorce, especially in the early } \\
\text { years of marriage. }\end{array}$ & 38 & 26.4 & 35 & 24.3 & 41 & 28.5 & 30 & 20.8 & 0.635 \\
\hline 13 & $\begin{array}{l}\text { The parent-child relationships are a } \\
\text { representation of how the child views } \\
\text { relationships not only with friends but also } \\
\text { with a romantic partner. }\end{array}$ & 69 & 47.9 & 42 & 29.2 & 25 & 17.4 & 8 & 5.6 & 0.752 \\
\hline 14 & $\begin{array}{l}\text { If you experienced the divorce of your parents, } \\
\text { unfortunately that doubles your risk for } \\
\text { divorce. }\end{array}$ & 42 & 29.2 & 33 & 22.9 & 41 & 28.5 & 28 & 19.4 & 0.639 \\
\hline
\end{tabular}


A Comparative Study of Academic Achievement of Undergraduates from Intact and Broken Homes in Obafemi Awolowo University, Ile-Ife, Osun State, Nigeria

\begin{tabular}{|l|l|l|l|l|l|l|l|l|l|}
\hline 15 & Would getting a divorce on the ground of & 62 & 43.1 & 32 & 22.2 & 34 & 23.6 & 16 & 11.1
\end{tabular} "infidelity and abuse" be appropriate?

Table 3 shows the factors contributing to broken home from the perspectives of undergraduates. It can be observed that insecure individuals are more likely to become unhappy in their marriages over time and divorce is considered as the foremost factors that can contribute to broken home. This factor comes under socio-economic status and insecurity and had the highest Relative Significance Index (RSI) of 0.781 .Also, $44.4 \%$ and $37.5 \%$ of the undergraduates agreed and strongly agreed to this factor while $11.1 \%$ and $6.9 \%$ of them disagreed and strongly disagreed. This is followed by "Having at least a modest income can help couples avoid stresses that can lead to divorce" with RSI value of 0.773 . While $58.3 \%$ and $27.1 \%$ of the undergraduates agreed and strongly agreed to this factor, $11.1 \%$ and $3.5 \%$ of them disagreed and strongly disagreed respectively. Next is "The parent child relationships are a representation of how the child views relationships not only with friends but also with a romantic partner" with RSI of 0.752 .This factor comes under early marriage and couples with divorced parents. In addition, $47.9 \%$ and $29.2 \%$ of the undergraduates agreed and strongly agreed to this factor whereas, $17.4 \%$ and $5.6 \%$ of them disagreed and strongly disagreed.

Another factor that is perceived as contributing to broken homes from undergraduates' perspective is feeling of disappointment if parents argue over money. This factor comes under socio-economic and insecurity and has RSI value of 0.750 . While $38.9 \%$ and $33.3 \%$ of the undergraduates respectively agreed and strongly agreed, $22.2 \%$ and $5.6 \%$ of them disagreed and strongly disagreed. Pregnancy and childbearing prior to marriage significantly increase the likelihood of future divorce" a factor under premarital cohabitation and premarital child bearing had RSI value of 0.700 with $34.7 \%$ and $27.8 \%$ of the undergraduates who agreed and strongly agreed. However, $27.1 \%$ and $10.4 \%$ of them disagreed and strongly disagreed.

It is also revealed that challenges leading to divorce could be traced to low income within the household, is considered as another factor that can lead to broken home. As it can be observed, this factor has the RSI value of 0.698 and $47.9 \%$ and $20.8 \%$ of the undergraduates agreed and strongly agreed whereas, $20.8 \%$ and $10.4 \%$ of them disagreed and strongly disagreed that such can contribute to broken home. Regarding whether getting a divorce on the ground of "infidelity and abuse" be appropriate or not, $43.1 \%$ and $22.2 \%$ of the undergraduates agreed and strongly agreed while $23.6 \%$ and $11.1 \%$ of them disagreed and strongly disagreed. This factor has RSI value of 0.691 among others. Another factor is suspicion which may likely occur between married couple as a result of their previous cohabitation. This factor has RSI value of 0.670 and $50.0 \%$ and $13.9 \%$ of the undergraduates agreed and strongly agreed that such could lead to broken home while $26.9 \%$ and $9.7 \%$ of them disagreed and strongly agreed.

Similarly, considerable percentage of the undergraduates believed that couples who live together before marriage appear to have a much higher chance of divorce if they marry. This factor has RSI value of 0.646 with $41.7 \%$ and $14.6 \%$ of the undergraduates who agreed and strongly agreed while $31.3 \%$ and $12 . / 5 \%$ of them disagreed and strongly disagreed. The chances of divorce as a result of coming from parents with similar experience had RSI value of 0.639 with $29.2 \%$ and $22.9 \%$ of the undergraduates who agreed and strongly agreed while $28.5 \%$ and $19.4 \%$ of them disagreed and strongly disagreed.

"Cohabitation is one of the reasons why marriages lead to divorce", and "marriage at a very young age increases the likelihood of divorce, especially in the early years of marriage" have the same RSI value of 0.635 .However, while $41.0 \%$ and $12.5 \%$ of the undergraduates agreed and strongly agreed to the former, $26.4 \%$ NS $24.3 \%$ of them agreed and strongly agreed to the latter. Also, $34.7 \%$ and $11.8 \%$ of the undergraduates disagreed and strongly disagreed to the former while $28.5 \%$ and $20.8 \%$ of them disagreed and strongly disagreed to the latter. Other factors identified as contributing to broken homes with their respective RSI values include couple compatibility (0.538), financial recklessness on the part of either of the couple, and cohabitation before formal marriage which is considered the least among other factors with RSI value of 0.481 .

\subsection{Hypothesis}

There is no significant difference in the academic achievement of the undergraduates from intact and broken homes. 
In order to test this hypothesis, academic achievements scores of the undergraduates measured through CGPA were subjected to t-test of independence. The result is presented in table 4 below.

Table4. T-test of Significant Difference in Academic Achievement of the Undergraduates from Intact and Broken Homes

\begin{tabular}{|l|l|l|l|l|l|l|c|}
\hline Achievements & \multicolumn{1}{|c|}{$\mathbf{N}$} & \multicolumn{1}{|c|}{ Mean } & Std. Deviation & Std. Error Mean & t & df & P \\
\hline Intact & 104 & 3.5577 & .93297 & .09148 & .596 & 67.467 & .542 \\
\hline Broken & 40 & 3.4500 & .98580 & .15587 & & & \\
\hline
\end{tabular}

Table 4 shows an independent sample t-test conducted to determine the differences in the academic achievement of the undergraduates from intact and broken homes. There is an indication from the result that there was no significant difference in the academic achievements of undergraduates from intact $(\mathrm{M}=3.56, \mathrm{SD}=0.93)$ and broken homes

$(\mathrm{M}=3.45, \mathrm{SD}=0.98)$ with $\mathrm{t}=.596, \mathrm{p}=.542$. Since the $\mathrm{p}$-value is greater than .05 , the stated null hypothesis is therefore not rejected. It can therefore be concluded that there is no significant difference in academic achievement of the undergraduates from intact and broken homes.

\section{DISCUSSION}

It could be said from the research question one as investigated that the academic achievement of the undergraduates from intact homes revealed from the Cumulative Grade Points Average (CGPA) as supplied through records based on the sample size in the selected faculties from intact home was subjected to descriptive analysis. The results showed that $75 \%$ of those from intact homes were either on $2^{\text {nd }}$ class lower of $2^{\text {nd }}$ class upper division, such as in the perspective of Ducan (2005), which stated that the relationship between home variable, meaning the intact home and its essentials and academic achievement are positive but the broken home has made it negative. In backing this assertion, one could see from the results that intact families contribute more to undergraduate's academic performance, but only $13 \%$ were on $1^{\text {st }}$ class division and the other respondents were either $3^{\text {rd }}$ class or a pass owning up to the view of Schults (2006) who found that if undergraduates from unstable homes are to be compared with those from stable homes, it would be seen that the former have more social, academic and emotional problems.

The research question two revealed that respondents from broken homes had far imaginable academic achievement of $80 \%$ who were on either $2^{\text {nd }}$ class lower or $2^{\text {nd }}$ class upper division. With this result, it can then be said that Ducan's (2005) findings do not correlate to people of Nigeria as to his sampled population do not include West Africans. While only $10.0 \%$ were on $1^{\text {st }}$ class division, this invariable answered the question that undergraduates from broken home are affected by the threats of divorce or separation of their parents. The research question three which investigated factors contributing to broken home from the perspectives of the undergraduates, such factors include: pre-marital cohabitation and pre-marital child bearing, socio-economic status and insecurity, early marriages and couples with divorced parents were subjected to a descriptive analysis.

From the findings, it could be said that majority of the respondents disagreed on the concept of cohabitation prior to marriage; this finding completely complemented the statement of National Health Resource Center under the UN (2011) and Adeyemi (2017) that living together is now common which is one of the impacts of broken homes and is on the increase. Agulana (2005) asserted that children of unmarried parents/separated families often fail and are at risk emotionally. In contrasting the view of UN (2011) and Agulana (2005), Hargreaves (1991) asserted that students' resilience in one-parent house hold is a significant indication of success in other area of their lives, including academics. He also pointed out that challenges have a way to motivate and take the best out of students from divorced/broken homes.

Furthermore, the socio-economic status and security revealed that $68.7 \%$ of the respondents agreed and strongly agreed that challenges in the family could be traced to low income leading to divorce while $85.4 \%$ of the respondents abruptly agreed and strongly agreed that a modest income can keep family together regardless of other challenges, just as revealed in Wallerstein and Blakeslee (2009) that changes in the economic and financial status of the family is a devastating consequences of 
divorce. Early marriages and couples with divorced parents revealed $70.8 \%$ agreement of future divorce for their children while $65.3 \%$ are of the opinion that divorce is appropriate on the ground of infidelity and abuse while $34.2 \%$ disagreed and strongly disagree, meaning that even if couples face challenges such as infidelity, they could still talk things over and resolve their differences.

The hypothesis indicated from the result that there was no significant difference in the academic achievements of undergraduates from intact and broken homes. Since the p-value is greater than .05 , we therefore do not reject the stated null hypothesis. It can therefore be concluded that there was no significant difference in academic achievement of the undergraduates from intact and broken homes. A research study by Hetherington, Stanley and Anderson (1997) noted that children from divorced homes did experience more psychological and behavioral problems than children from intact homes, therefore $70 \%$ to $80 \%$ of these children emerged as "reasonably competent and well-adjusted individuals" after a time of readjustment to the divorce. Such has been established in this study so far but this claim against the view of Keith and Amato (1991), that examined children from divorced and remarried families, the investigation revealed that these children are more likely to have academic problems, externalizing and internalizing disorders, lower self-esteem and social incompetency.

\section{CONClusion}

The study concluded that most of the respondents were not staying with their parents. They performed below expectation due to the lack of security, care, parental failure and discipline. It should be noted that undergraduates are fast growing and the society is changing into a global world beyond expectations. Undergraduates learn new things every day and if parents do not play the essential role they are to play, sooner or later the young stars lose focus and academic failure begins to set in beyond a reasonable measure. The study further concluded that some of the factors which cause academic failures linked to divorce, such as cohabitation, early marriage, family income, trust and insecurity between couples should be discouraged, curbed, in order to reduce the likelihood of broken home. This will enable the society to be a better place to race kids for the betterment of the generality.

\section{RECOMMENDATIONS}

- The government should create academic and counseling units in higher institutions of learning with adequate fund, while undergraduates from broken homes should be given proper guidance and counseling concerning their psychological needs and social problems towards their studies for appropriate discipline.

- Proper monitoring, security and discipline should be given to the undergraduates by their guidance and single parents.

- Parents should be enlightened on the need to stay together as husband and wife to raise a good family. They should persevere and tolerate each other in marriage.

- Religious scholars should expose parents to dangers of broken homes and their effect on academic achievement of the learners irrespective of their levels.

- Government should review upward minimum salary from the current amount to reasonable and substantial level to better the lives of the average citizens in the country.

- There is need for personal, social, group counseling and individual counseling in schools where students with challenged homes are counseled. Students at all levels should develop positive self-concept in life to assist them in their academic achievements.

\section{REFERENCES}

[1] Adeyemi, B. A. (2017).Influence of parental conflict on the academic performance of married students in tertiary institutions in Osun State, Nigeria Canadian Journal for Social Science and Education Volume 10 Pp. 119-134.

[2] Agulana, G. G. (2005).Family structure and prevalence of behavioural problems among Nigerian adolescents.The Counselor7(1), 154-161.

[3] Ajila, C. \& Olutola, A. (2007).Impact of Parents' socio-economic status on University student's academic performance: Ife Journal of Education Studies. 7(1), 31-39 
[4] Akanbi, M. I. (2014).Impact of Divorce on Academic Performance of Senior Secondary Students in Ilorin Metropolis, Kwara State.

[5] Akinboye, J. O. (2006).Definitions of Emotional Intelligence from Creativity Paradigm. CYFO Behavioral Services. Department of Guidance and Counseling, University of Ibadan, Ibadan.

[6] Aremu, C. A. (2012).Path Analytical Investigation of Some Factors Affecting Juvenile Delinquency among Secondary School Adolescents in South-West Nigeria. A PH.D Seminar Presentation, University of Ibadan, Nigeria.

[7] Children's Defense Fund (2004).The State of America's Children.Year Book, Washington D.C.

[8] Demo, D. H. \& Cox, M. (2000).Families with Young Children: A Review of Research in the 1990.Journal of Marriage and the Family.Pg 876-895.

[9] Ducan, R. E. (2005).Principled of teaching spectrum books limited, Jublee House King Road, P.M.B. Ibadan.

[10] Frazer, W. J. (2001).Family Structure, Parental Practices and High School completion.AmericanSociology Review, (56), 309-320.

[11] Hargreaves, M. (1991).Learning under stress:Children of single parents and the schools, Metuchen, NJ: Women's Action Alliance and the Scarecrow Press, Inc. Africa, South African Journal of Psychology, 37(2), 260-283.

[12] Hetherington, E., Stanley-Hagan, M., and Anderson, E. (1997).Marital transitions: A Child's Perspective.American Psychologist, 44, 303-313.

[13] Ichado, S. M. (1998).Impact of Broken Home on Academic Performance of SecondarySchool Student in English Language.Journal of Research in Counseling Psychology, 4, 47-87.

[14] Keith, B. \& Amato, P. R. (1991).Parental divorce and well-being of children.Psychological Bulletin, 11(1), 26-46.Resources, ERIC Journal pg 34-42.

[15] Laura, N. Martin., Specter, G., \& Martin, D. (2009).A Review of Literature on the Impact of Parental Divorce on Relationships in Adolescents. An Unpublished Master's thesis in Guidance and Counseling.

[16] Maduewesi \& Emeogu, U. (1997).Nurturing the Adolescents in Nigeria today:The role of the family, the school and government.The Nigerian Teacher Today (TNTT).A journal of teacher Education, 5 (1 \& 2), 39-42.

[17] Nzewunwah, P. N. (1995).The Effect of Single Parent-Hood on the Academic Performance of Students.Unpublished M.Ed. Project, University of Lagos, Lagos.

[18] Okoye, N. N. (2003).Are Boys bettern than Girls in Mathematics and English Language in academic performance? Psychology for everyday living 2, 21-27.

[19] Omoruyi, I. V. (2014).Influence of Broken Homes on Academic Performance and Personally Development of the Adolescents in Lagos State Metropolis. European Journal of Educational and Development Psychology 2(2) pp 10-23.

[20] Rodgers, B., \& Pryor, C. (1998).Parental divorce and adult psychological distress:Evidence from a National Birth Cohort.Journal of Child Psychology and Psychiatry and Allied Disciplines. Pg 867-872.

[21] Salami, S. O. \& Alawode, E. A. (1999).Influence of Single Parenting on Academic Achievement of Adolescent in Secondary School: Implication for Counseling. An Unpublished Handout, Department of Guidance and Counseling, University of Ibadan, Ibadan.

[22] Salami, B. O. \&Alawode, W. S. (2000).Actiology, Treatment and Prevention of Juvenile Delinquency among Secondary School Adolescents in Nigeria. Journal of Research in Education. 2 (11)1-8.

[23] Schults, G. (2006).Broken Family Structure Leads to Educational Difficulties for Children. Journal of Educational Psychology. 27, 70-80.

[24] Tenibiaje, D. J. (2009).Influence of Family size and family birth order on academic performance of adolescents in higher institution.Pakistan Journal of social Sciences, 6(3), 110-114.

[25] Tre, S. (2005).The Schol Compositional Effect of Single Parenthood on $10^{\text {th }}$ grade achievement. Sociology of Education, 71(1), 23-42. The Subject Matter of Marriage.(Wikipedia, the free encyclopedia).

[26] UNESCO (2003).Students do better when their fathers are involved t school (OECD) Publication No. 98121).Retrieved from http://UNESCO.ed.gov/pubs98/98121.pdf.

[27] United Nation (2011).Caring for Our Children: National Health and Safety Performance Standards Guidelines for Early Care and Educator Programmes, $3^{\text {rd }}$ Edition Reviewed from http://ww.cfoc.nrckids.org.FAQ.cfm.

[28] Ushie, M. A., Emeka, J. O., Ononga, G. I., \& Owolabi, E. O. (2012).Influence of Family Structure on Students' Academic Performance in Agege Local Government Area, Lagos State, Nigeria European Journal of Educational studies 4(2), 177-187.

[29] Wallerstein, Y. and Blakeslee, R. J. (2009).Children as collective goods and divorce settlements. Journal of Labour Economics 3 (3), 268-292. 
A Comparative Study of Academic Achievement of Undergraduates from Intact and Broken Homes in Obafemi Awolowo University, Ile-Ife, Osun State, Nigeria

[30] Yusuf, G. A. \& Eweniyi S. K., (2005).Resiliency among Inner-City Youths from Selected Areas of Ibadan City, Nigeria:Intervening Protective Factors in Response to Risk and Disadvantage.Kamla-Raj Journal of Social Sciences. 9(3): 177-184.

\section{AUTHOR'S BIOGRAPHY}

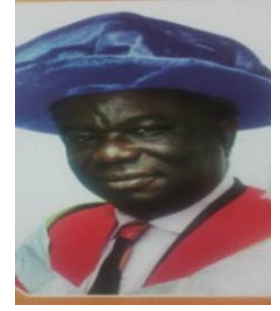

Dr. B.A Adeyemi is an associate professor in the Institute of Education, Faculty of Education, Obafemi Awolowo University, Ile-Ife, Osun State, Nigeria. His areas of specialization are Social Studies Education, Curriculum Studies, Educational Evaluation and Primary Education. He has over 70 articles published in various outlets- locally, nationally and internationally. He is happily married with children.

Citation: Dr. B. A. Adeyemi. "A Comparative Study of Academic Achievement of Undergraduates from Intact and Broken Homes in Obafemi Awolowo University, Ile-Ife, Osun State, Nigeria". International Journal of Humanities Social Sciences and Education (IJHSSE), vol 5, no. 7, 2018, pp. 26-35. doi: http://dx.doi.org/10.20431/2349-0381.0507005.

Copyright: () 2018 Authors. This is an open-access article distributed under the terms of the Creative Commons Attribution License, which permits unrestricted use, distribution, and reproduction in any medium, 